\title{
Hematological parameters and frequency of salmonella spp. in swabs of caiman yacare after of probiotics
}

The $\mathrm{C}$. yacare placed in breeding conditions have a preserved genetic pool, which requires the enhancement of its zootechnical characteristics to solve some obstacles. Among them is the natural occurrence of Salmonella spp. in wild C. yacare. To address this problem, some breeders have adopted the use of probiotics to reduce Salmonella spp. in the digestive tube of crocodilians. The purpose of this study was to verify whether the addition of probiotics in animal feed reduces the isolation frequency of Salmonella spp. in cloacal swabs and to assess whether the additive interferes with the hematology and the complement system. During an 18 -month period, four groups of caimans received $0 \%$ (control group), $0.25 \%, 0.5 \%$ and $1 \%$ of probiotic supplement. The probiotics did not reduce the isolation frequency of Salmonella spp. We have identified directly proportional relation between probiotic concentration and Hemoglobin concentration ( $\mathrm{Hb}$ ) and Mean Corpuscular Hemoglobin Concentration ( $\mathrm{MCHC}$ ) and inversely proportional relation to the total concentration of Eosinophils and Heterophils. Finally, we verify that the prolonged use of probiotics at $0.25 \%$ concentration is safe and increase the activity of the complement system.

Keywords: Probiotic; Hemoglobin; Salmonella; Complement; Erythrocytes.

\section{Parâmetros hematológicos e frequência de salmonella spp. em suabes de caiman yacare após uso de probióticos}

O pool genético dos $C$. yacare colocados em condições de cultivo é preservado, o que requer o aprimoramento de suas características zootécnicas para transpor alguns obstáculos. Entre eles está a ocorrência de Salmonella spp. em C. yacare em animais selvagens trazidos para o ambiente de cultivo. Para resolver esse problema, alguns criadores adotaram o uso de probióticos para reduzir a presença de Salmonella spp. no tubo digestivo desses crocodilianos. O objetivo deste estudo foi verificar se a adição de probióticos na alimentação animal reduz a frequência de isolamento de Salmonella spp. em suabes cloacais e para avaliar se o aditivo interfere na hematologia e no sistema complemento. Durante um período de 18 meses, quatro grupos de jacarés receberam $0 \%$ (grupo controle), $0,25 \%$, $0,5 \%$ e $1 \%$ de suplementação de probiótico. Os probióticos não reduziram a frequência de isolamento de Salmonella spp. Foi verificada uma relação diretamente proporcional entre a concentração de probiótico com a concentração de hemoglobina ( $\mathrm{Hb}$ ), bem como com a Concentração de Hemoglobina Corpuscular Média e relação inversamente proporcional à concentração total de Eosinófilos e Heterófilos. Finalmente, verificamos a segurança e o aumento da atividade do sistema do complemento no uso prolongado de probióticos a uma concentração de $0,25 \%$.

Palavras-chave: Probióticos; Hemoglobina; Salmonella; Complemento; Eritrócitos.

Topic: Uso Sustentável da Biodiversidade

Reviewed anonymously in the process of blind peer.
Received: 10/06/2018

Approved: $24 / 07 / 2018$
Giovani Spinola de Carvalho Instituto Federal de Mato Grosso, Brasil http://lattes.cnpq.br/7703943714930715 giovani.carvalho@cas.ifmt.edu.br

\section{Alessandro Spinola Bérgamo}

Instituto Federal de Mato Grosso, Brasil http://lattes.cnpq.br/3010511688228818 alessandrovet31@gmail.com

\section{Vitor M. Aleixo}

Instituto Federal de Mato Grosso, Brasil aleixovm@uol.com.br

$\begin{aligned} & \text { Alexandre C. Veiga } \\ & \text { Universidade do Estado de Mato Grosso, Brasil } \\ & \text { alebiologo10@outlook.com }\end{aligned}$
Luciana M. Moreira
Instituto Federal de Mato Grosso, Brasil
lucianamelhoranca@gmail.com
Terezinha Knöbl 10
Universidade de São Paulo, Brasil
http://lattes.cnpq.br/2848262283092226
http://orcid.org/0000-0001-7107-5710
veterinaria.tk@gmail.com

Mirela Caroline V. Oliveira Universidade de São Paulo, Brasil mirela.vilela@usp.br

Maria Gabriela X. Oliveira Universidade de São Paulo, Brasil mariagabriela@usp.br

Ricardo M. Borges

Universidade de São Paulo, Brasil borgesrm@gmail.com

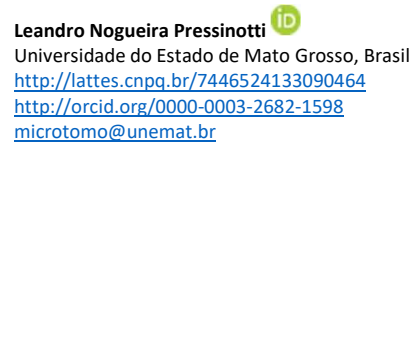

Referencing this:

CARVALHO, G. S.; BÉRGAMO, A. S.; ALEIXO, V. M.; VEIGA, A. C.; MOREIRA, L. M.; KNÖBL, T.; OLIVEIRA, M. C. V.; OLIVEIRA, M. G. X.; BORGES, R. M.; PRESSINOTTI, L. N.. Hematological parameters and frequency of salmonella spp. in swabs of caiman yacare after of probiotics. Revista Ibero Americana de Ciências Ambientais, v.9, n.5, p.51-63, 2018. DOI: http://doi.org/10.6008/CBPC2179$\underline{6858.2018 .005 .0006}$

DOI: 10.6008/CBPC2179-6858.2018.005.0006 


\section{INTRODUCTION}

The planet's largest density of crocodilians is found in the flooded regions of Argentina, Bolivia, Brazil and Paraguay. This and the resilience of the Caiman yacare population allows the sustainable management of the species (FARIAS et al., 2013), presenting as an alternative to environmental preservation and income for the Pantanal population (HARRIS et al., 2005; NOGUEIRA et al., 2011). Aiming to optimize the breeding system for Pantanal caimans, some work fronts have sought to enhance the zootechnical characteristics of caimans, optimizing weight gain, improving health conditions and reducing mortality rates (ALEIXO et al., 2002; MACIEL et al., 2003). As a result, it is possible to point out some obstacles to breeding, such as feeding and sanitation in the zootechnical systems. Even though C. yacare present high tolerance to infections, poor hygiene conditions may increase the risks of epizootic outbreaks due to foster of potential pathogenic/zoonotic bacteria (PRESSINOTTI et al., 2013; SCOTT; FOSTER, 1997). In Brazil, federal law regulates $C$. yacare breeding in the ranching system, where an annual quota of wild egg harvest and hatchlings capture are determined by the population size of the species (BAMPI et al., 2002; VERDADE, 2004). The negative side of this model is the introduction of microorganisms found in wild populations into the breeding system, which may maximize sanitary risks and increase the need of controls even further. Among other bacteria, different serovars of Salmonella spp. make up the natural gut microbiota of wild and farmed caimans (AUSTRALIA, 2000; HUCHZERMEYER, 2002; MITCHELL et al., 2001; UHART et al., 2011), with some serovars considered potentially zoonotic (MADSEN et al., 1998).

The ingestion of contaminated caiman meat, the contact with live caimans or with the environment where caimans evacuate are potential contamination routes to humans by these bacteria (ENG et al., 2015). Crocodilian meat may be contaminated by Salmonella spp. during slaughter and processing, but these crossed contamination risks may be mitigated by hygiene, monitory and treatment strategies (AUSTRALIA, 2000). However, the presence of Salmonella spp may debilitate C. yacare (HUCHZERMEYER, 2002; MITCHELL et al., 2001), making necessary to control the presence of this bacteria in the microbiota. As a prophylactic measure, caiman feeding can be supplemented with probiotics to promote competitive exclusion and/or produce bactericide substances capable of reducing the frequency of Salmonella spp. in the digestive tube. The probiotics are used to improve the health condition of its consumers and may vary depending on the supplement doses, frequency, and treatment length. Moreover, the microorganisms acting as probiotics are species-specific, so that generalizations regarding the actions of a certain microorganism combination in distinct zootechnical species may be misleading (GATESOUPE, 1999; HAI, 2015). The literature highlights the probiotic effect of the bacteria Enterococcus faecium (OLIVEIRA et al., 2014), Lactococcus lactis (DOYLE; ERICKSON, 2012), Bacillus subtilis (SADEGHI et al., 2015), Bifidobacterium spp., (IÑIGUEZ PALOMARES et al., 2006), Lactobacilus acidophilus (PRISCILLA et al., 2008; VANDEPLAS et al., 2010) and Lactobacilus casei (HUDAULT et al., 1997). There is no published data on use of probiotics in crocodilians. Because of the occurrence of Salmonella spp. in the digestive tube of $C$. yacare, we tested a commercial probiotic composed by combination of Bifidobacterium bifidum, Bacillus subtilis, Enterococcus faecium, Lactobacillus acidophilus, 
Lactobacillus casei and Lactobacillus lactis as feed additive (BERGE et al., 2012). The systemic effects of the use of probiotics were verified by evaluating the activity of the alternative pathway of the complement system and by hematologic parameters (GATESOUPE, 1999; HAl, 2015). Once use of probiotics represents an alternative to diminishing the prevalence of Salmonella spp in the gut and improvement of general health conditions, it is necessary to study the hematological parameters and frequency of Salmonella spp in cloacal swabs in $C$. yacare after the prolonged use of probiotics.

\section{MATERIALS AND METHODS}

The $C$. yacare used herein (120 sub-adults of 3-year and 2-month-old; see table 2 for Snout-Vent Length) were made available by a legal ranch located in the State of Mato Grosso (Brazil), where they are farmed in a barn with $4.0 \mathrm{~m}^{2}$ brick stalls on uneven floor and with water available in one third of this area (ALEIXO et al., 2002). This study was carried out in accordance with federal laws on use and handling of wild animals and the protocol was approved by the Brazilian Institute of Environment and Renewable Natural Resources (IBAMA), the Authorization and Biodiversity Information System (SISBio), Brazil (number 42831)

\section{Experimental Design}

Feeding was carried out three times a week and provided at $5 \%$ of live weight of the animals, with a diet based on ground bovine viscera, soymeal, limestone, vitamins A, D3, E, K3, B1, B2, B6, B12, Biotine, Niacine, Calcium Panthotenate, Folic Acid, Manganese, Zinc, Iron, Copper, Iodine, Selenium (ALEIXO et al., 2002; MARCÓ; PIÑA; LARRIERA, 2009), and supplemented with commercial probiotic Nutrimix Aves ${ }^{\circledR}$ (Base Fértil, São Paulo, Brazil, MAPA EPSP07471). The probiotic used contains vitamin A, butylated hydroxytoluene (BHT), methionine, lysine, flavoring agent, Bifidobacterium bifidum, Bacillus subtilis, Enterococcus faecium, Lactobacillus acidophilus, Lactobacillus casei, Lactobacillus lactis.

Four concentrations of probiotics supplementation were used. The $120 \mathrm{C}$. yacare were randomly distributed into control group that did not receive addition of probiotics in the feed or three remaining groups that received additions of $0.25 \%, 0.5 \%$ or $1 \%(\mathrm{w} / \mathrm{w})$ of probiotics in the feed for a period of 18 months. We assayed 29, 31, 30 and 30 caimans in the control, $0.25 \%, 0.5 \%$ and $1 \%$ groups respectively (Table 1 ).

Table 1: Final concentration of probiotics at $0.25 \%, 0.50 \%$ and $1 \%$ in the feed offered to $C$. yacare.

\begin{tabular}{|l|l|l|l|}
\hline Probiotic Concentration & $0,25 \%$ & $0,50 \%$ & $1 \%$ \\
\hline vitamin A & $6.5 \mathrm{UI} / \mathrm{g}$ & $13 \mathrm{UI} / \mathrm{g}$ & $26 \mathrm{UI} / \mathrm{g}$ \\
\hline BHT & $0.0025 \mathrm{mg} / \mathrm{g}$ & $0.005 \mathrm{mg} / \mathrm{g}$ & $0.01 \mathrm{mg} / \mathrm{g}$ \\
\hline Methionine & $0.0075 \%$ in mass & $0.015 \%$ in mass & $0.03 \%$ in mass \\
\hline Lysine & $0.0075 \%$ in mass & $0.015 \%$ in mass & $0.03 \%$ in mass \\
\hline Flavoring agent & $0.175 \%$ in mass & $0.35 \%$ in mass & $0.70 \%$ in mass \\
\hline Bifidobacterium bifidum & $595 \mathrm{UFC} / \mathrm{g}$ & $1190 \mathrm{UFC} / \mathrm{g}$ & $2380 \mathrm{UFC} / \mathrm{g}$ \\
\hline Bacillus subtilis & $875 \mathrm{UFC} / \mathrm{g}$ & $1750 \mathrm{UFC} / \mathrm{g}$ & $3500 \mathrm{UFC} / \mathrm{g}$ \\
\hline Enterococcus faecium & $595 \mathrm{UFC} / \mathrm{g}$ & $1190 \mathrm{UFC} / \mathrm{g}$ & $2380 \mathrm{UFC} / \mathrm{g}$ \\
\hline Lactobacillus acidophilus & $595 \mathrm{UFC} / \mathrm{g}$ & $1190 \mathrm{UFC} / \mathrm{g}$ & $2380 \mathrm{UFC} / \mathrm{g}$ \\
\hline Lactobacillus casei & $560 \mathrm{UFC} / \mathrm{g}$, & $1120 \mathrm{UFC} / \mathrm{g}$, & $2240 \mathrm{UFC} / \mathrm{g}$, \\
\hline Lactobacillus lactis & $300 \mathrm{UFC} / \mathrm{g}$. & $600 \mathrm{UFC} / \mathrm{g}$. & $1200 \mathrm{UFC} / \mathrm{g}$. \\
\hline
\end{tabular}

BHT = Butylated hydroxytoluene 


\section{Hematology}

The number of caimans sampled were $23,23,24$ and 25 in the control, $0.25 \%, 0.5 \%$ and $1 \%$ groups respectively. The maximum blood volume collected was $0.3 \%$ of live weight of the caimans, not detrimental to the viability of the organisms after sampling (NARDINI; LEOPARDI; BIELLI, 2013; SYKES; KLAPHAKE, 2008). Blood was harvested from the spinal venous sinus located continuously with the tail to the occipital condyle (MYBURGH et al., 2014; SYKES et al., 2008) with aid of a needle and syringe, previously treated with heparin solution ( $1 \mathrm{~mL}$ of $5.000 \mathrm{U}$ heparin for $50 \mathrm{~mL}$ of $0.9 \%$ saline solution) after asepsis with iodine $2 \%$ (AREE et al., 2011; MYBURGH et al., 2014). The hematology evaluation was adapted from fish to crocodilians. Blood smeared on glass slides were stained by May Grünwald and Giemsa (ROSENFELD, 1947) and total cell counting was determined using Neubauer chamber (NARDINI et al., 2013). The hematocrit percentage (Ht) was determined by the microcapillary method (RANZANI-PAIVA et al., 2013), whereas total hemoglobin was determined by the cyanometahemoglobin method (Hb) (COLLIER, 1944) using laboratory kit for human hemoglobin (Labtest, Brazil). Total leukocyte counting was determined by the relative count (RANZANI-PAIVA et al., 2013). A total of 2,000 cells were counted in blood smears, distinguishing between erythrocytes (Er), thrombocytes (Tr) and leukocytes (Lc). Subsequently, the numbers were used in the indirect calculation of these cell types concentration (RANZANI-PAIVA et al., 2013). With the aforesaid hematimetric parameters, we calculated Mean Corpuscular Volume (MCV), Mean Corpuscular Hemoglobin (MCH), and Mean Corpuscular Hemoglobin Concentration (MCHC):

$$
\mathrm{MCV}=\frac{\mathrm{Ht}(\mathrm{L} / \mathrm{L}) \times 1000}{\operatorname{Er}\left(\mathrm{pL}^{-1}\right)}=\mathrm{fL} \quad \mathrm{MCH}=\frac{\mathrm{Hb}\left(\frac{\mathrm{g}}{\mathrm{dL}}\right) \times 10}{\operatorname{Er}\left(\mathrm{pL}^{-1}\right)}=\mathrm{pg} \quad \mathrm{MCHC}=\frac{\mathrm{Hb}\left(\frac{\mathrm{g}}{\mathrm{dL}}\right)}{\mathrm{Ht}\left[\frac{\mathrm{L}}{\mathrm{L}}\right]}=\%
$$

The leukogram was performed by active search in glass slides blood smears of monocytes, lymphocytes, eosinophils, heterophils and basophils until counting 200 cells (GREER et al., 2014).

\section{Activity of the alternative pathway of the Complement System}

The efficiency of the Complement System was assessed by the method of sheep (Ovis aries) Er hemolysis. An Er suspension was prepared in PBS pH 7,4 at 2\% concentration (v/v) (SRBC - Suspension of Red Blood Cells) (MERCHANT, 2012; MERCHANT et al., 2006; SIROSKI et al., 2010). A total of $20 \mathrm{~mL}$ of blood was harvested from each of the 30 C. yacare, distributed as 8, 7, 9 and 6 C. yacare in the control, 0.25\%, 0.5\% and $1 \%$ probiotic groups respectively, with aid of non-heparinized syringes. Blood was transferred into $15 \mathrm{~mL}$ test tubes, allowed to coagulate for 4 hours at 25ㅇ C and centrifuged at 2,000 g allowing blood serum to be harvested. Absorbance was blanked with a $2 \mathrm{~mL}$ mixture of PBS and $2 \mathrm{~mL}$ of serum. Serum and SRBC were incubated for 5 minutes at 30 C. All incubations were centrifuged for sedimentation of non-hemolyzed Er and the hemoglobin released on the supernatant was estimated by spectrophotometry at the $540 \mathrm{~nm}$ wavelength (AREE et al., 2011; MERCHANT, 2012). Negative control (0\% hemolysis) consisted of heat inactivation of $2 \mathrm{~mL}$ serum (56ㅇ C for $30 \mathrm{~min}$ ) and subsequently tested by incubation with $2 \mathrm{~mL}$ SRBCs for 5 minutes (ISBERG, 2007; FINGER et al., 2012; MACHHA et al., 2011). Positive control (100\% hemolysis) 
consisted of incubating $2 \mathrm{~mL}$ SRBCs with $2 \mathrm{~mL}$ of $2 \%$ Triton-X, aggressively homogenized with an insulin syringe. Total hemolysis was assessed in microscope before absorbance measuring.

\section{Frequency of Salmonella spp.}

Cloacal swabs were sampled once at the end of the 18 months period from all the $120 \mathrm{C}$. yacare of the experimental design. The swabs were inoculated in Stuart medium and kept refrigerated until being selectively enriched in sodium tetrathionate broth at $37^{\circ} \mathrm{C}$ for $48 \mathrm{~h}$, followed by plating in XLT4 selective medium and reincubation at $37^{\circ} \mathrm{C}$ for $24-48 \mathrm{~h}$ (MEAD et al., 1989). The identification of isolates was carried out through a biochemical series medium (Enterokit - Probac ${ }^{\circledR}$, São Paulo, Brazil) and was confirmed serologically with polyvalent somatic commercial antigen (Probac ${ }^{\circledast}$, São Paulo, Brazil). Isolates were kept in storage mediums and sent to the strains collection.

Bacterial genomic DNA was extracted as previous described (BOOM et al., 1990) to confirm genus Salmonella spp. by Polymerase Chain Reaction (PCR) (ALVAREZ et al., 2004). Amplification was performed using $50 \mu \mathrm{L}$ of the mixture containing $20 \mathrm{ng}$ of DNA, $1.5 \mathrm{mM} / \mathrm{L}$ of $\mathrm{MgCl}, 0.2 \mathrm{mM} / \mathrm{L}$ of each dNTP, $0.4 \mu \mathrm{M}$ of each oligonucleotide, $1 \mathrm{U}$ of Taq enzyme DNA polymerase (LGC Biotecnologia, São Paulo, Brazil), 1 X PCR buffer and ultrapure water. The amplified fragments were visualized after $1.5 \%$ agarose gel electrophoresis, stained by BlueGreen ${ }^{\circledast}$ (LGC Biotecnologia, São Paulo, Brazil), and amplicon sizes identified with the assistance of a 100 base pair molecular marker.

\section{Data analysis}

Data are presented as descriptive statistics and Kruskal-Wallis non-parametric test was used for testing the hypothesis of hematological differences between treatments and control. The Mann-Whitney $U$ non-parametric test was used for testing the differences in the hemolysis test. Differences in Salmonella spp. frequency between treatments and control was tested by chi-square. Linear regressions were traced in dispersion graphs correlating probiotic concentration and the measured parameters, and tested by ANOVA F Test.

\section{RESULTS}

\section{Hematology}

$\mathrm{SVL}, \mathrm{Er}, \mathrm{Lc}, \mathrm{Ht}, \mathrm{Hb}, \mathrm{MCV}, \mathrm{MCH}$ results and total concentration of monocytes, lymphocytes, basophils and heterophils were not significantly different among treatments. MCHC values were significantly higher for caimans receiving $1 \%$ probiotics compared to the control group. Total eosinophils concentration presented lower levels in caimans receiving $0.5 \%$ probiotics compared to the control group (Table 2 ).

Table 2: Hematological analysis of $C$. yacare at probiotic concentration of $0 \%, 0.25 \%, 0.5 \%$ and $1 \%$.

\begin{tabular}{|l|l|l|l|l|}
\hline $\mathrm{PbC}$ & $\mathbf{0 \%}$ & $\mathbf{0 . 2 5 \%}$ & $\mathbf{0 . 5 \%}$ & $\mathbf{1 \%}$ \\
\hline $\mathrm{SVL}$ & $57.73 \pm 3.50$ & $60.73 \pm 4.32$ & $58.83 \pm 4.12$ & $59.40 \pm 2.51$ \\
\hline $\mathrm{Er} / \mathrm{uL}$ & $53.7510^{4} \pm 10.5210^{4}$ & $55.7710^{4} \pm 8.9610^{4}$ & $56.9210^{4} \pm 9.4710^{4}$ & $58.0710^{4} \pm 8.3910^{4}$ \\
\hline
\end{tabular}




\begin{tabular}{|l|l|l|l|l|}
\hline $\mathrm{Lc} / \mathrm{uL}$ & $11.2310^{3} \pm 4.4610^{3}$ & $12.8310^{3} \pm 7.4810^{3}$ & $11.9410^{3} \pm 6.0210^{3}$ & $11.9710^{3} \pm 5.2710^{3}$ \\
\hline $\mathrm{Ht} \%$ & $24.74 \pm 2.78$ & $24.78 \pm 3.46$ & $24.46 \pm 3.02$ & $25.28 \pm 3.38$ \\
\hline $\mathrm{Hb}(\mathrm{g} / \mathrm{dL})$ & $9.24 \pm 1.83$ & $9.80 \pm 1.93$ & $10.05 \pm 2.25$ & $10.63 \pm 2.61$ \\
\hline $\mathrm{MCV}(\mathrm{fL})$ & $474.13 \pm 88.13$ & $452.71 \pm 82.69$ & $437.27 \pm 69.57$ & $438.26 \pm 46.61$ \\
\hline $\mathrm{MCH}(\mathrm{pg})$ & $176.41 \pm 42.09$ & $180.03 \pm 46.12$ & $178.75 \pm 40.57$ & $184.00 \pm 40.87$ \\
\hline $\mathrm{MCHC}(\mathrm{g} / \mathrm{dL})$ & $37.43^{\mathrm{a}} \pm 6.50$ & $39.58^{\mathrm{ab}} \pm 5.86$ & $41.02^{\mathrm{ab}} \pm 7.20$ & $41.99^{\mathrm{b}^{*} \pm 7.80}$ \\
\hline Total Monocytes & $766.07 \pm 463.36$ & $819.77 \pm 487.58$ & $679.90 \pm 299.94$ & $709.10 \pm 406.92$ \\
\hline Total Lymphocytes & $6996.98 \pm 2738.58$ & $9479.313 \pm 5259.58$ & $9529.21 \pm 5361.10$ & $9178.96 \pm 4109.67$ \\
\hline Total Eosinophils & $806.14^{\mathrm{a}} \pm 639.62$ & $655.15^{\mathrm{ab}} \pm 624.82$ & $348.25^{\mathrm{b} *} \pm 376.84$ & $442.30^{\mathrm{ab}} \pm 325.12$ \\
\hline Total Basophils & $251.06 \pm 225.62$ & $242.08 \pm 307.74$ & $196.98 \pm 167.37$ & $158.30 \pm 132.26$ \\
\hline Total Heterophils & $2410.38 \pm 1879.74$ & $1634.33 \pm 1685.90$ & $1190.01 \pm 738.45$ & $1486.91 \pm 1097.61$ \\
\hline
\end{tabular}

$\mathrm{PbC}$, Probiotic Concentration; SVL, Snout-Vent Length; Er, Erythrocytes; Ht, Hematocrit; Hb, Hemoglobin; Lc, Leukocytes; MCH, Mean Corpuscular Hemoglobin; MCV, Mean Corpuscular Volume; MCHC, Mean Corpuscular Hemoglobin Concentration. Different letters refer to significant differences between the columns. The $p$ value was calculated using the Kruskal-Wallis non-parametric test. * $\mathrm{p}=0,014, * * \mathrm{p}=0,004$.

Linear regressions of $\mathrm{Hb}$ and $\mathrm{MCHC}$ were significantly and directly proportional to the probiotic concentration (Figure 1). Concentrations of eosinophils and heterophils were significantly and inversely proportional to the $\mathrm{PbC}$ as shown by the linear regression (Figure 2).
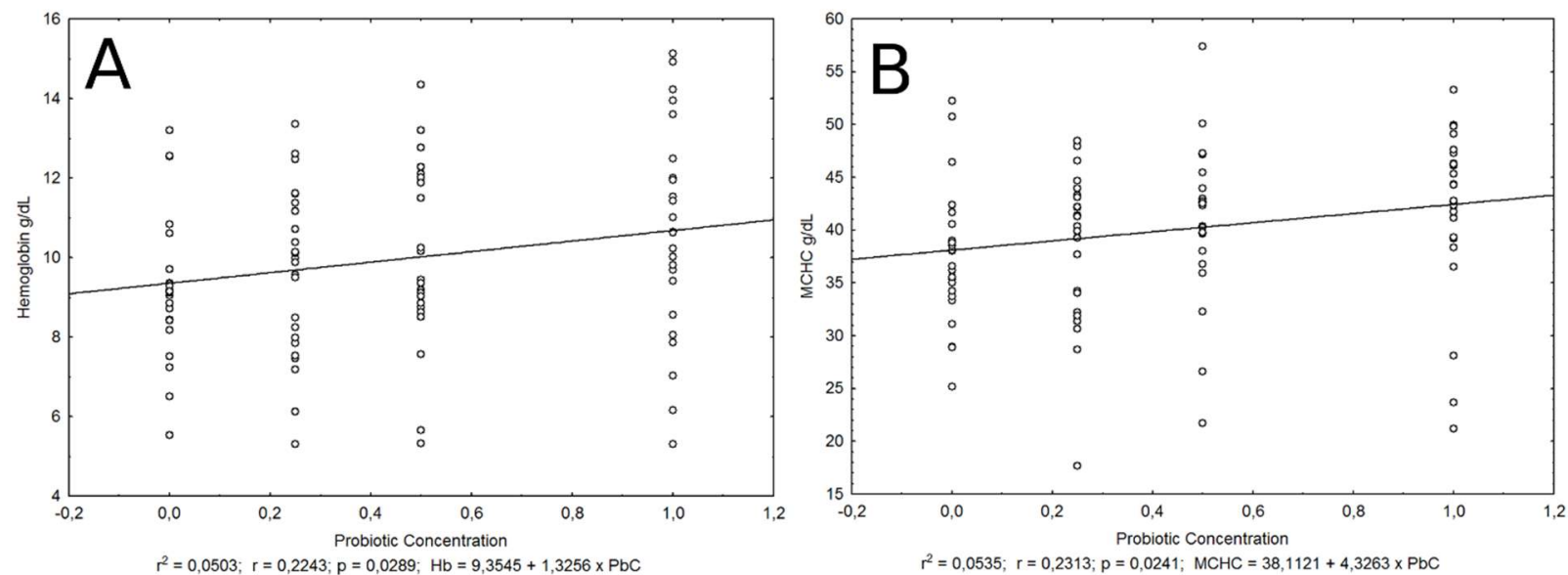

Figure 1: Linear regression graphs of parameters directly proportional to probiotic concentration. (A) Probiotic Concentration vs Hemoglobin. (B) Probiotic Concentration vs Mean Corpuscular Hemoglobin Concentration. $p<0.05$. Correlation levels and the linear equations are shown. Footnote: $\mathrm{PbC}$, Probiotic Concentration; $\mathrm{Hb}$, hemoglobin; $\mathrm{MCHC}$, Mean Corpuscular Hemoglobin Concentration
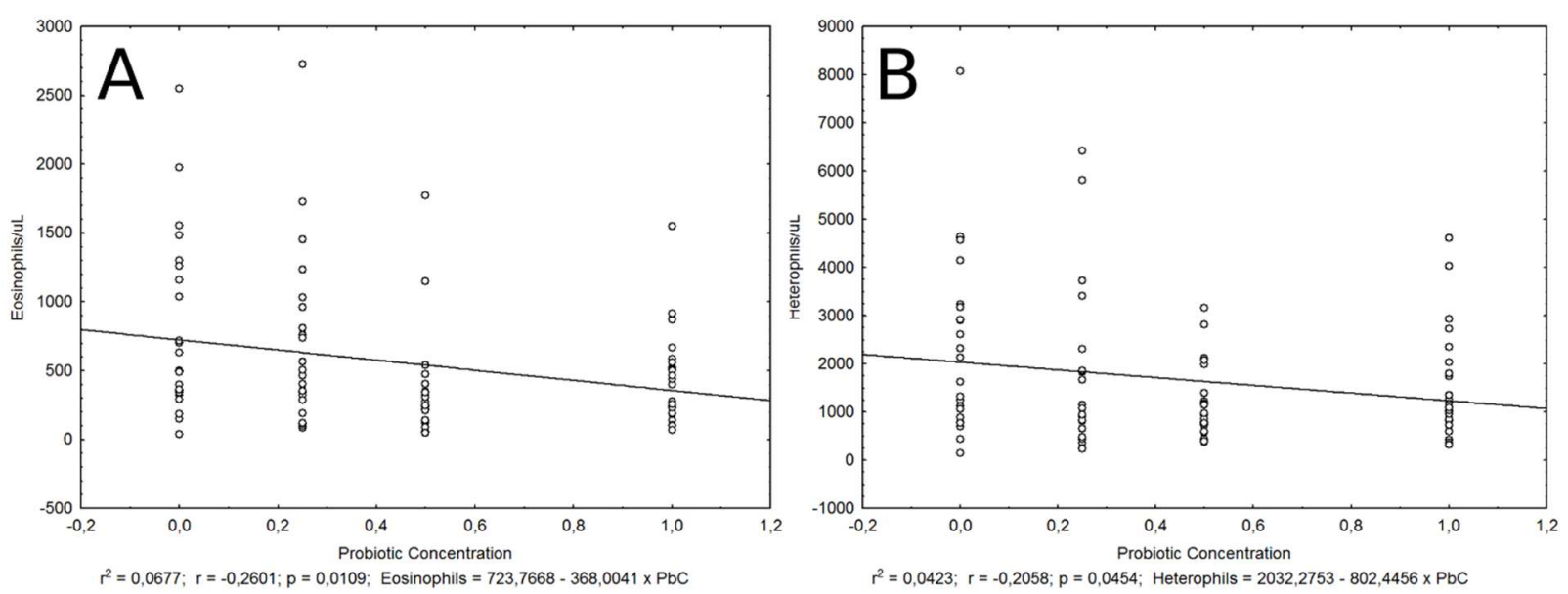

Figure 2: Linear regression graphs of parameters inversely proportional to probiotic concentration. (A) Probiotic Concentration vs Eosinophils / $\mu \mathrm{L}$. (B) Probiotic Concentration vs Heterophils $/ \mu \mathrm{L} . \mathrm{p}<0.05$. Correlation levels and the linear equations are shown. Footnote: $\mathrm{PbC}$, Probiotic Concentration. 


\section{Activity of the alternative pathway of the Complement System}

Hemolysis values of caimans receiving probiotics at $0.25 \%$ concentration were significantly higher when compared to the control group (Table 3).

Table 3: Hemolysis of serum from C. yacare treated with different concentrations of probiotics.

\begin{tabular}{|l|l|l|l|l|}
\hline $\mathrm{PbC}$ & SVL & Hemolysis \% Mean & $\mathbf{- 9 5 \%}$ & $\mathbf{+ 9 5 \%}$ \\
\hline $0 \%$ & 58.81 & 12.83 & 3.64 & 22.02 \\
\hline $0.25 \%$ & 64.00 & $23.75^{*}$ & 14.76 & 32.74 \\
\hline $0.5 \%$ & 60.50 & 20.44 & 8.25 & 32.63 \\
\hline $1 \%$ & 60.10 & 15.40 & 5.11 & 25.70 \\
\hline
\end{tabular}

$\mathrm{PbC}$, Probiotic Concentration; SVL, Snout-Vent Length. * Significant difference according to Mann-Whitney U in comparison to control. $p<0.01$. Inactivation by EDTA or serum heated at $56{ }^{\circ} \mathrm{C}$ fully inhibited hemolysis.

\section{Frequency of Salmonella spp.}

Salmonella spp. was present in $13.79 \%$ of cloacal swabs from the control group, in $22.58 \%, 40 \%$ and $43.33 \%$ of cloacal swabs, respectively, from $0.25 \%, 0.5 \%$ and $1 \%$ probiotic groups. There were no significant differences in the occurrences reported among treatments.

\section{DISCUSSION AND CONCLUSIONS}

To our knowledge, there are no prior reports on the use of probiotics in crocodilian feeding, consequently, our starting point were the already established protocols used for studies in other animal groups, such as birds and fish. In such studies, the use of probiotics allows colonization of the gut by a different microbiota, improving the immune system and antimicrobial activity (GATESOUPE, 1999; HAI, 2015; SMITH, 2014). Improvements in weight gain (RAMOS et al., 2015), immunomodulation (BALCÁZAR et al., 2006) and hematological profile changes (SADEGHI et al., 2015) are correlated to the use of probiotics; however, the biological processes explaining the cause and consequence relations are still being investigated (HOU et al., 2015).

The prolonged use of probiotics did not change $\mathrm{Ht}$ values, which are within the expected range for $C$. yacare (BARBOZA et al., 2004; 2007; 2012; KOZA et al., 2012; VIEIRA et al., 2002). C. yacare are ectothermic, and the temperature of the environment interferes with sex determination (PINHEIRO et al., 2001), development (MIRANDA et al., 2002) and hematimetric indexes (BARBOZA et al., 2004), such as the Ht. Other conditions also provoke variations in reptiles $\mathrm{Ht}$ besides the temperature, such as blood viscosity (BARBOZA et al., 2004) and age group, but there is no significant difference when other parameters are taken into account, such as sexes and species, or if farmed versus wild caimans (BARBOZA et al., 2010; PADILLA et al., 2011). Caimans of the same age were used herein in order to minimize $\mathrm{Ht}$ physiological variations correlated to weight gain and aging (BARBOZA et al., 2007). Ht increase may result of stress caused by the confinement of caimans, which basal levels resume to normal levels after 8 hours (BARBOZA et al., 2007). The lowest Ht averages are found in ranching system animals (BARBOZA et al., 2007; 2011), that can be explained by the fact that these animals are used to constant handling, reducing confinement stress. We highlight that no $C$. yacare deaths were registered throughout the experiment. In addition, visual body score indicated the 
maintenance of a healthy status in all caimans. This corroborate the hypothesis that there are healthy $C$. yacare with $\mathrm{Ht}$ lower than $20 \%$, considering the minimum reference level for maintenance of the healthy status in reptiles (STACY et al., 2011). Hb results of the control and supplemented treatments are considered higher than the reference for $C$. yacare (KOZA et al., 2012), potentially correlated to feeding regularity, constant management and/or lower thermal fluctuation (VIEIRA et al., 2002) when compared to values for caimans described in the literature. This can be explained by the fact that the $C$. yacare sampled in this experiment are kept in ranching conditions at latitudes near the Equator, lower altitude and near the geodesic point of the continent, free of ocean air masses and, therefore, under more constant weather conditions. The higher $\mathrm{Hb}$ values increased $\mathrm{MCH}$ and $\mathrm{MCHC}$ values. $\mathrm{MCH}$ values described in the literature vary between warm and cold seasons (BARBOZA et al., 2010), and the values obtained in this study correspond to the values described for the warm season, corroborating our hypothesis regarding the latitude of the animals in the experiment. MCHC of $C$. yacare presented higher values compared to the values obtained in the Northeast region of Argentina (BARBOZA et al., 2004). The MCHC values obtained in this study were higher, as registered for $C$. yacare maintained in the ranching system (BARBOZA et al., 2007). Thus, the constant management may contributed to the increase of $\mathrm{Hb}$ and, as a consequence, of $\mathrm{MCHC}$. The use of probiotics did not change the $\mathrm{MCH}$, as observed in the $O$. mykiss fish (CRETU et al., 2013). The MCV measures the volume of red blood cells, indicating and classifying different types of anemia. The MCVs of farmed caimans were higher than those found in the literature (BARBOZA et al., 2010, 2011), which can be explained by the geographical location of the $C$. yacare in this experiment.

Lyophilized probiotics use the antioxidant butylated hydroxytoluene (BHT) as preserver (CASTRO, 2017). In mice, BHT at $3 \mathrm{~g} / \mathrm{kg}$ may originate hepatocellular carcinomas, increases platelet count, $\mathrm{Er}$, $\mathrm{Ht}$ and $\mathrm{Hb}$ and decreases leukocytes (COTTRELL et al., 1994). In Rhesus monkeys, $50 \mathrm{mg} / \mathrm{kg}$ concentrations during 2 years did not significantly influence $\mathrm{Hb}, \mathrm{Ht}$, and white and red blood cells (EFSA, 2012). In this study, the highest BHT concentration was of $10 \mathrm{mg} / \mathrm{kg}$. Vitamin $\mathrm{A}$ is frequently added to probiotics as compensation for hepatic losses of vitamin caused by BHT (CASTRO, 2017). Experiments with methionine supplementation at $1.20 \%$ concentration of feed increased leukogram in mice (WEBB et al., 2003); in early-stage broiler chickens, methionine supplementation at concentrations from $0.19 \%$ to $0.64 \%$ increased white blood cells (ADEYEMO et al., 2010) and significantly increased hematimetric parameters (AL-MAYAH, 2006). In fish, lysine supplementation at concentrations from $0.69 \%$ to $3.08 \%$ of dry diet incremented weight, growth and hematology (WANG et al., 2005), stimulated growth and nutrient retention (BICUDO et al., 2009).

In this study, supplementation was lower than the aforesaid concentrations, thus, it is unlikely that methionine, lysine or the BHT led to the highlighted hematological results, such as $\mathrm{Hb}$ increase and granulocyte count decrease. When compared to mammal leukocytes, atypical leukocytes, such as azurophils and heterophils, stand out. Azurophils are small cells with unspecific azurophilic granules and, in crocodilians, they are considered monocyte morphological variations. Heterophils present acidophil, elliptical granulation, with similar role to neutrophils (NARDINI et al., 2013; STACY et al., 2011; SYKES et al., 2008). The percentage 
of monocytes obtained corresponds to the values established for $C$. yacare (BARBOZA et al., 2010). Probiotics may increase the number of Oreochromis niloticus monocytes (NAKANDAKARE et al., 2013), which has not been investigated in this study. The percentage of lymphocytes is in accordance with the literature available, as for C. yacare in Argentina. Lymphocyte concentrations vary greatly, reaching up to $33 \%$ in wild caimans (FUENTES et al., 2011). The year's season and age increase may reduce the concentration of lymphocytes in C. yacare (BARBOZA et al., 2010; 2012). The use of probiotics may act as immunostimulant, increasing the number of lymphocytes (GATESOUPE, 1999), which may take place in response to the colonization of the digestive tube, increasing the number of lymphocytes and other leukocytes (TEVES et al., 2012). However, lymphocyte concentration did not differ significantly between treatments.

Eosinophils in mammals are responsible for the defense against parasites, but information on this matter in reptiles is scarce (ZIMMERMAN et al., 2010). A diet based on bone meal, crude protein, ethereal extract, calcium and phosphorus may increase the number of eosinophils (BARBOZA et al., 2011); however, it did not significantly influence the percentage of eosinophils in $R$. catesbeiana frogs (FRANÇA et al., 2008). In reptiles we find eosinophil count in the range between 7 and 20\% active against Staphylococcus aureus and protozoans (STACY et al., 2011). The eosinophil concentration found was higher than the values reported in the literature for $C$. yacare from Northeast of Argentina kept in ranching conditions (BARBOZA et al., 2010). Higher results of eosinophils in the control group may be explained by the positive correlation with temperature or the persistence of some preexistent challenge as parasitoses. The reduction of eosinophils in the peripheral blood of the treated caimans may be related to decrease or preexistent gut parasitoses by probiotics, thus, presenting less haematopoiesis. Maintaining the concentration of basophils in all treatments weakens the hypothesis of an allergic condition or chronic inflammation. It has been reported that the number of basophils in $R$. catesbeiana did not change with the use of probiotics (FRANÇA et al., 2008).

In the literature, the percentage of heterophils is not consensual, and there is great discrepancy between the values presented for crocodilians (BARBOZA et al., 2010). Some species of crocodilians present higher frequency of heterophils instead of lymphocytes (FUENTES et al., 2011) and vice versa (BARBOZA et al., 2010). Heterophils are the first cells to reach the infection (LATORRE et al., 2012). The concentration of heterophils observed is not indicative of the existence of acute infection, since our values are low compared to the literature (HARIKRISHNAN et al., 2011). The decrease of eosinophils and heterophils concentration inversely proportional to probiotic concentration may be related to problems in haematopoiesis of granulocytes caused by exhaustion of physiological condition after probiotic overstimulation.

In O. mykiss, immunostimulation was observed with feed supplementation with $0.22 \%$ of probiotics (CRETU et al., 2013). In caimans, the greatest activity of the alternative pathway of the complement system happened at concentration of $0.25 \%$ of probiotics, concomitantly to the maintenance of the values of the other parameters compared to the control, corroborating the hypothesis that the $0.25 \%$ concentration is the most appropriate. Doses higher than $0.25 \%$ may have caused physiological disturbances such as reduction in weight gain in caimans (data to be published) and disrupting the haematopoiesis of granulocytes. 
There was an attempt to minimize the frequency of Salmonella spp in the digestive tube of $C$. yacare with the use of probiotics, but the extended use was no effective to reduce the number of animals colonized by Salmonella spp, under these study conditions. Further studies are required to verify whether there are quantitative differences in bacterial cell counts in the digestive tract of probiotic-treated and untreated animals, establishing more effective and safe protocols for $C$. yacare.

In this study, we addressed a prolonged use of probiotics for a period of 18 months. This constant use may have different effects compared to the use for short periods, that is, part of the effects in the hematological and immunological parameters may be due to the energy depletion and saturation of the physiological phenomena, such as innate immunity. Considering the values presented in this study in $0.25 \%$ supplementation with probiotics, it is possible to assert that this dosage is safe even after an 18-month chronic treatment. At this concentration, we verified the maintenance of the hematological parameter with an increase of activity in the complement system. Finally, the use of probiotics at $0.25 \%$ concentration may constitute an interesting management strategy to be tested on the basis of its immunostimulation, even though the mixture is not sufficient to prevent shedding of Salmonella spp at the cloaca.

\section{REFERENCES}

ADEYEMO, G. O.; OLOGHOBO, A. D.; ADEBIYI, O. A.. The Effect of Graded Levels of Dietary Methionine on the Haematology and Serum Biochemistry of Broilers. International Journal of Poultry Science, v.9, n.2, p.158-161, 2010. DOI: http://doi.org/10.3923/ijps.2010.158.161

AL-MAYAH, A. A. S.. Immune response of broiler chicks to DL-methionine supplementation at different ages. International Journal of Poultry Science, v.5, n.2, p.169-172, 2006.

ALEIXO, V. M.; COTTA, T.; LOGATO, P. V. R.; OLIVEIRA, A. I. G.; FIALHO, E. T.. Efeitos da adição de diferentes teores de farelo de soja na dieta sobre o desenvolvimento de filhotes de jacaré-do-pantanal [Caiman yacare (Daudin, 1802)]. Ciências Agrotecnicas Lavras, v.26, p.411-417, 2002.

ALVAREZ, J.; SOTA, M.; VIVANCO, A. B.; PERALES, I.; CISTERNA, R.; REMENTERIA, A.; GARAIZAR, J.. Development of a multiplex PCR technique for detection and epidemiological typing of Salmonella in human clinical samples. Journal of Clinical Microbiology, v.42, n.4, p.17341738, 2004. DOI: http://doi.org/10.1128/JCM.42.4.1734$\underline{1738.2004}$

AREE, K.; SIRUNTAWINETI, J.; CHAEYCHOMSRI, W.. Crocodylus siamensis serum and macrophage phagocytic activity. Journal of the Medical Association of Thailand = Chotmaihet thangphaet, v.94, n.7, p.131-138, 2011.

AUSTRALIA. Importation of Crocodile Meat from Zimbabwe into Australia Draft Import Risk Analysis Paper. 2000.

BALCÁZAR, J. L.; VENDRELL, D.; BLAS, I.; RUIZ-ZARZUELA, I.; GIRONÉS, O.; MUZQUIZ, J. L.. Immune modulation by probiotic strains: Quantification of phagocytosis of Aeromonas salmonicida by leukocytes isolated from gut of rainbow trout (Oncorhynchus mykiss) using a radiolabelling assay. Comparative Immunology, Microbiology and Infectious Diseases, v.29, n.5-6, p.335-343, 2006. DOI: http://doi.org/10.1016/j.cimid.2006.09.004

BAMPI, M. L.; COUTINHO, M.. Policy for the Conservation and management of jacaré (Caiman yacare) in Brazil. In: INTERNATIONAL WORKSHOP FOR MANAGEMENT AND TRADE OF CAIMAN YACARE. Anais. Gainesville, 2002.

BARBOZA, N. N. et al. Variaciones estacionales del eritrograma durante el cautiverio de Caiman latirostris y Caiman yacare (Crocodylia: Crocodylidae). In: UNIVERSIDAD NACIONAL DEL NORDESTE COMUNICACIONES CIENTÍFICAS Y TECNOLÓGICAS. Anais. 2004.

BARBOZA, N. N.; MUSSART, N. B.; COPPO, J. A.; FIORANELLI, S. A.; KOZA, G. A.. Oscilaciones del eritrograma en caimanes criados por sistema ranching. Revista Veterinaria, v.18, n.2, p.84-91, 2007.

BARBOZA, N. N.; PANSERI, A. F.; MUSSART, N. B.; KOZA, G. A.; COPPO, J. A.. Análisis multivariado de los cambios hemáticos y morfométricos de Caiman latirostris y Caiman yacare según especie, sexo y estación del año. Revista Veterinaria, v.21, n.2, p.112-122, 2010.

BARBOZA, N. N.; PANSERI, A. F.; MUSSART, N. B.; KOZA, G. A.; COPPO, J. A.. Variación de indicadores nutricionales en 'yacarés' (Caiman latirostris) alimentados con distintas dietas en un criadero de Chaco, Argentina. Revista Veterinaria, v.22, n.1, p.1-9, 2011.

BARBOZA, N. N.; MUSSART, N. B.; KOZA, G. A.; COPPO, J. A. Internal environment in juvenile specimens of Caiman latirostris and Caiman yacare from Argentina. Physiological variations according to species, sex, liveweight, size, and 
season of the year. Revista electrónica de Veterinaria, v.13, n.3, 2012.

BERGE, A. C.; WIERUP, M.. Nutritional strategies to combat Salmonella in mono-gastric food animal production. Animal, v.6, n.4, p.557-564, 2012. DOI:

http://doi.org/10.1017/S1751731111002217

BICUDO, Á. J. A.; SADO, R. Y.; CYRINO, J. E. P.. Dietary lysine requirement of juvenile pacu Piaractus mesopotamicus (Holmberg, 1887). Aquaculture, v.297, n.1-4, p.151-156, 2009. DOI:

http://doi.org/10.1016/j.aquaculture.2009.09.031

BOOM, R.; SOL, C. J. A.; SALIMANS, M. M. M.; JANSEN, C. L.; WERTHEIM-VAN DILLEN, P. M. E.; VAN DER NOORDAA, J.. Rapid and simple method for purification of nucleic acids. Journal of Clinical Microbiology, v.28, n.3, p.495-503, 1990.

CASTRO, L. S.; BRACHT, L.; COMAR, J. F.; PERALTA, R. M.; BRACHT, A.. A reappraisal of the proposed metabolic and antioxidant actions of butylated hydroxytoluene (BHT) in the liver. Journal of Biochemical and Molecular Toxicology, v.31, n.8, p.11, 2017. DOI: http://doi.org/10.1002/ibt.21924

COLLIER, H. B.. Standardization of blood haemoglobin determinations. Canadian Medical Association Journal, v.50, n.6, p.550-552, 1944.

COTTRELL, S. et al. Haematological and platelet effects of butylated hydroxytoluene (BHT, E321). Comparative Haematology International, v.4, n.2, p.102-107, 1994. DOI: http://doi.org/10.1007/BF00368276

CRETU, M. M.; CRISTEA, V.; LORENA, D.. The effect of probiotic diet on growth and hematology parameters of rainbow trout (Oncorhynchus mykiss, Walbaum 1792). Lucrări Ştiinţifice-Seria Zootehnie, v.59, p.258-263, 2013.

DOYLE, M. P.; ERICKSON, M. C.. Opportunities for mitigating pathogen contamination during on-farm food production. International journal of food microbiology, v.152, n.3, p.5474, 16 jan. 2012. DOI:

http://doi.org/10.1016/i.ijfoodmicro.2011.02.037

EFSA. Scientific Opinion on the re-evaluation of butylated hydroxytoluene BHT (E 321) as a food additive. EFSA Journal, v.10, n.3, p.2588, 2012. DOI:

http://doi.org/10.2903/j.efsa.2012.2588

ENG, S. K. et al. Salmonella : A review on pathogenesis, epidemiology and antibiotic resistance. Frontiers in Life Science, p.1-10, 2015. DOI:

http://doi.org/10.1080/21553769.2015.1051243

FARIAS, I. P.; MARIONI, B.; VERDADE, L. M.; BASSETTI, L.; COUTINHO, M. E.; MENDONÇA, S. H. S. T.; VIEIRA, T. Q.; MAGNUSSON, W. E.; CAMPOS, Z.. Avaliação do risco de extinção do jacaré-do-pantanal Caiman yacare (Daudin, 1802) no Brasil. Biodiversidade Brasileira, v.3, n.1, p.21-30, 2013.

FINGER JR, J. W.; ISBERG, S. R.. A review of innate immune functions in crocodilians. CAB Reviews: Perspectives in Agriculture, Veterinary Science, Nutrition and Natural
Resources, v.7, n.67, p.1-11, 2012. DOI:

http://doi.org/10.1079/PAVSNNR20127067

FRANÇA, F. M.; DIAS, D. C.; TEIXEIRA, P. C.; MARCANTÔNIO, A. S.; STÉFANI, M. V.; ANTONUCCI, A.; ROCHA, G.; RANZANIPAIVA, M. J. T.; FERREIRA, C. M.. Efeito do probiótico Bacillus subtilis no crescimento, sobrevivência e fisiologia de Rãstouro (Rana catesbeiana). Boletins do Instituto de Pesca, v.34, n.3, p.403-412, 2008.

FUENTES, A. G. M.; SEIJAS, A. E.; ROSSINI, M.. Valores hematológicos en ejemplares jóvenes de Caimán del Orinoco (Crocodylus intermedius) en Venezuela. Revista Cientifica Facultad de Ciencias Veterinarias, v.21, n.4, p.360-364, 2011.

GATESOUPE, F.. The use of probiotics in aquaculture. Aquaculture, v.180, n.1-2, p. 147-165, out. 1999. DOI: http://doi.org/10.1016/S0044-8486(99)00187-8

GREER, J. P.; ARBER, D. A.; GLADER, B.; LIST, A. F.; MEANS JR., ROBERT T.; PARASKEVAS, F.; RODGERS, G. M.. Wintrobe's Clinical Hematology. 13 ed. Philadelphia: Wolters Kluwer Lippincott Williams \& Wilkins Health, 2014.

HAI, N. V.. The use of probiotics in aquaculture. Journal of Applied Microbiology, v.119, n.4, p.917-935, 2015. DOI: http://doi.org/10.1111/jam.12886

HARIKRISHNAN, R.; KIM, M.-C.; KIM, J.-S.; BALASUNDARAM, C.; HEO, M.-S.. Probiotics and herbal mixtures enhance the growth, blood constituents, and nonspecific immune response in Paralichthys olivaceus against Streptococcus parauberis. Fish and Shellfish Immunology, v.31, n.2, p.310317, 2011. DOI: http://doi.org/10.1016/i.fsi.2011.05.020

HARRIS, M. B.; TOMAS, W. M.; MOURÃO, G.; SILVA, C. J.; GUIMARÃES, E.; SONODA, F.; FACHIM, E.. Desafios para proteger o Pantanal brasileiro: ameaças e iniciativas em conservação. Megadiversidade, v.1, n.1, p.156-164, 2005.

HOU, C.; ZENG, X.; YANG, F.; LIU, H.; QIAO, S.. Study and use of the probiotic Lactobacillus reuteri in pigs: a review. Journal of animal science and biotechnology, v.6, n.1, p.14, 2015. DOI: http://doi.org/10.1186/s40104-015-0014-3

HUCHZERMEYER, F. W.. Diseases of farmed crocodiles and ostriches. Revue scientifique et technique (International Office of Epizootics), v.21, n.2, p.265-276, 2002.

HUDAULT, S.; LIÉVIN, V.; BERNET-CAMARD, M.-F.; SERVIN, A. L.. Antagonistic activity exerted in vitro and in vivo by Lactobacillus casei (strain GG) against Salmonella Typhimurium C5 infection. Appl. Envir. Microbiol., v.63, n.2, p.513-518, 1997.

IÑIGUEZ PALOMARES, C.; ACEDO FÉLIX, E.. Mecanismos de adhesión al tracto intestinal y antagonismo de Bifidobacterium. Revista Salud Publica y Nutrición, v.7, n.2, 2006.

ISBERG, S.. Nutrition of juvenile saltwater crocodiles (Crocodylus porosus) in commercial production systems. CAB Reviews: Perspectives in Agriculture, Veterinary Science, Nutrition and Natural Resources, v.2, n.91, p.1-11, 2007. DOI: http://doi.org/10.1079/PAVSNNR20072091 
KOZA, G. A.; MUSSART, N. B.; BARBOZA, N. N.; COPPO, J. A.. Respuesta bioquímica y morfométrica a la incorporación de pescado, pollo y carne vacuna en la dieta de Caiman yacare en cautiverio. Revista Veterinaria, v.23, n.2, p.110-115, 2012.

LATORRE, M. A.; GONZÁLEZ, E. C. L.; LARRIERA, A.; POLETTA, G. L.; SIROSKI, P. A.. Effects of in vivo exposure to Roundup ${ }^{\circledR}$ on immune system of Caiman latirostris. Journal of immunotoxicology, v.10, n.4, p.349-54, 2012. DOI: http://doi.org/10.3109/1547691X.2012.747233

MACHHA, V.; SPENCER, P.; MERCHANT, M.. Effects of Leukocyte Extract from the American Alligator (Alligator mississippiensis) on Antibiotic-Resistant Bacteria. The Open Zoology Journal, v.4, p.9-13, 2011. DOI: http://doi.org/10.2174/1874336601104010009

MACIEL, F. R.; LOGATO, P. V. R.; FIALHO, E. T.; FREITAS, R. T. F.; ALEXIO, V. M.. Coeficiente de digestibilidade aparente de cinco fontes energéticas para o jacaré-do-pantanal (Caiman yacare, Daudin, 1802). Ciência e Agrotecnologia, v.27, n.3, 2003. DOI: http://doi.org/10.1590/S141370542003000300024

MADSEN, M.; HANGARTNER, P.; WEST, K.; KELLY, P.. Recovery rates, serotypes, and antimicrobial susceptibility patterns of salmonellae isolated from cloacal swabs of wild Nile crocodiles (Crocodylus niloticus) in Zimbabwe. Journal of zoo and wildlife medicine: official publication of the American Association of Zoo Veterinarians, v.29, n.1, p.3134, 1998.

MARCÓ, M. V. P.; PIÑA, C. I.; LARRIERA, A.. Food conversion rate (FCR) in Caiman latirostris resulted more efficient at higher temperatures. Interciencia, v.34, n.6, p.428-431, 2009.

MEAD, G. C.; BARROW, P. A.; HINTON, M. H.; HUMBERT, F.; IMPEY, C. S.; LAHELLEC, C.; MULDER, R. W. A. W.; STAVRIC, S.; STERN, N. J.. Recommended assay treatment of chickens to prevent Salmonella colonization by 'competitive exclusion'. Journal of Food Protection, v.52, n.7, p.500-502, 1989.

MERCHANT, M.. Characterization of serum complement activity in serum of the Komodo dragon (Varanus komodoensis). Advances in Biological Chemistry, v.2, n.4, p.353-359, 2012. DOI:

http://doi.org/10.4236/abc.2012.24043

MERCHANT, M.; BRITTON, A.. Characterization of serum complement activity of saltwater (Crocodylus porosus) and freshwater (Crocodylus johnstoni) crocodiles. Comparative biochemistry and physiology. Part A, Molecular \& integrative physiology, v.143, n.4, p.488-93, 2006. DOI: http://doi.org/10.1016/i.cbpa.2006.01.009

MIRANDA, M. P.; MORAES, G. V.; MARTINS, E. N.; MAIA, L. C. P.; BARBOSA, O. R.. Thermic Variation in Incubation and Development of Pantanal Caiman (Caiman crocodilus yacare) (Daudin, 1802) Kept in Metabolic Box. Brazilian. Archives of Biology and Technology, v.45, n.3, p.333-342, 2002.
MITCHELL, M. A.; SHANE, S. M.. Salmonella in reptiles. Seminars in Avian and Exotic Pet Medicine, v.10, n.1, p.2535, 2001. DOI: http://doi.org/10.1053/saep.2001.19798

MYBURGH, J. G.; KIRBERGER, R. M.; STEYL, J. C. C.; SOLEY, J. T.; BOOUSE, D. G.; HUCHZERMEYER, F. W.; LOWERS, R. H.; GUILLETTE JR., L. J.. The post-occipital spinal venous sinus of the Nile crocodile Crocodylus niloticus: its anatomy and use for blood sample collection and intravenous infusions. Journal of the South African Veterinary Association, v.85, n.1, p.965, 2014.

NAKANDAKARE, I. B.; IWASHITA, M. K. P.; DIAS, D. C.; TACHIBANA, L.; RANZANI-PAIVA, M. J. T.; ROMAGOSA, E.. Incorporação de probióticos na dieta para juvenis de tilápiasdo-nilo: Parâmetros hematológicos, imunológicos e microbiológicos. Boletim do Instituto de Pesca, v.39, n.2, p.121-135, 2013.

NARDINI, G.; LEOPARDI, S.; BIELLI, M.. Clinical Hematology in Reptilian Species. Veterinary Clinics of North America Exotic Animal Practice, v.16, n.1, p.1-30, 2013. DOI: http://doi.org/10.1016/i.cvex.2012.09.001

NOGUEIRA, S. S. C.; NOGUEIRA-FILHO, S. L. G.. Wildlife farming: An alternative to unsustainable hunting and deforestation in Neotropical forests? Biodiversity and Conservation, v.20, n.7, p 1385-1397, 2011. DOI: http://doi.org/10.1007/s10531-011-0047-7

OLIVEIRA, J. E. et al. In ovo inoculation of chicken embryos with probiotic bacteria and its effect on posthatch Salmonella susceptibility. Poultry science, v.93, n.4, p.81829, 2014. DOI: http://doi.org/10.3382/ps.2013-03409

PADILLA, S. E.; WEBER, M.; JACOBSON, E. R.. Hematologic and plasma biochemical reference intervals for Morelet's crocodiles (Crocodylus moreletii) in the northern wetlands of Campeche, Mexico. Journal of wildlife diseases, v.47, n.3, p.511-522, 2011. DOI: http://doi.org/10.7589/0090-355847.3.511

PINHEIRO, M. S.; ANDREOTI E SILVA, R.; SANTOS, S. A. Observations on the thermal selection of the Pantanal Caiman (Caiman crocodilus yacare) hatchlings (Crocodylia : Alligatoridae). Rev. Brasil. Biol., v.61, n.2, p.323-327, 2001. DOI: http://doi.org/10.1590/S0034-71082001000200016

PRESSINOTTI, L. N.; BORGES, R. M.; LIMA, A. P. A.; ALEIXO, V. M.; IUNES, R. S.; BORGES, J. C. S.; COGLIATI, B.; SILVA, J. R. M. C.. Low temperatures reduce skin healing in the Jacaré do Pantanal (Caiman yacare, Daudin 1802). Biology open, v.2, n.11, p.1171-1178, 2013. DOI:

http://doi.org/10.1242/bio.20135876

DELFINO, T. P. C.. Sinergismo entre substâncias antimicrobianas e Lactobacillus acidophilus na inibição de Salmonella enteritidis e Salmonella gallinarum. Tese (Doutorado) - Universidade Estadual Paulista, São Paulo, 2008.

RAMOS, M. A.; GONÇALVES, J. F. M.; BATISTA, S.; COSTAS, B.; PIRES, M. A.; REMA, P.; OZÓRIO, R. O. A.. Growth, immune responses and intestinal morphology of rainbow trout (Oncorhynchus mykiss) supplemented with 
commercial probiotics. Fish \& Shellfish Immunology, v.45, 2015. DOI: http://doi.org/10.1016/i.fsi.2015.04.001

ROSENFELD, G.. Corante pancrômico para hematologia e citologia clínica. Nova combinação dos componentes do May-Grünwald e do Giemsa num só corante de emprego rápido. Memorias do Instituto Butantan, v.20, p.329-334, 1947.

SADEGHI, A. A.; SHAWRANG, P.; SHAKORZADEH, S.. Immune response of Salmonella challenged broiler chickens fed diets containing Gallipro ${ }^{\circledR}$, a Bacillus subtilis probiotic. Probiotics and Antimicrobial Proteins, v.7, n.1, p.24-30, 2015. DOI: http://doi.org/10.1007/s12602-014-9175-1

SCOTT, T.; FOSTER, B. G.. Salmonella spp. in free-ranging and farmed alligators (Alligator mississippiensis) from Texas and Louisiana, U.S.A. Aquaculture, v.156, n.1-2, p.179-181, 1997.

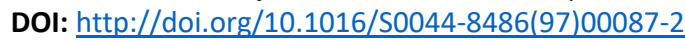

SIROSKI, P. A.; MERCHANTE, M.;MARCÓ, M. V. P.; PIÑA, C. I.; ORTEGA, H. H.. Characterization of serum complement activity of the broad snouted caiman (Caiman latirostris, Crocodilia). Zoological Studies, v.49, n.1, p.64-70, 2010.

SMITH, J. M.. A Review of Avian Probiotics. Journal of Avian Medicine and Surgery, v.28, n.2, p.87-94, 2014. DOI: http://doi.org/10.1647/2012-031

STACY, N. I.; ALLEMAN, A. R.; SAYLER, K. A.. Diagnostic Hematology of Reptiles. Clinics in Laboratory Medicine, v.31, n.1, p. 87-108, mar. 2011. DOI:

http://doi.org/10.1016/j.cll.2010.10.006

SYKES, J. M.; KLAPHAKE, E.. Reptile hematology. The veterinary clinics of North America. Exotic animal practice, v.11, n.3, p.481-500, 2008. DOI:

http://doi.org/10.1016/i.cll.2015.05.014

TEVES, P. M.; SALGADO, E. M.. Probióticos , prebióticos y simbióticos en el síndrome de intestino irritable. Acta Medica Peruana, v.29, n.2, p.92-98, 2012.
UHART, M.; FERREYRA, H.; MATTIELLO, R.; CAFFER, M. I.; TERRAGNO, R.; SCHETTINO, A.; PRADO, W.. Isolation of Salmonella spp. from yacare caiman (Caiman yacare) and broad-snouted caiman (Caiman latirostris) from the Argentine Chaco. Journal of Wildlife Diseases, v.47, n.2, p.271-277, 2011. DOI: http://doi.org/10.7589/0090-3558$\underline{47.2 .271}$

VANDEPLAS, S.; DAUPHIN, R. D.; BECKERS, Y.; THONART, P.; THÉWIS, A.. Salmonella in chicken: current and developing strategies to reduce contamination at farm level. Journal of food protection, v.73, n.4, p.774-785, 2010. DOI: http://doi.org/10.4315/0362-028X-73.4.774

VERDADE, L. M.. A exploração da fauna silvestre no Brasil: Jacarés, sistemas e recursos humanos. Biota Neotropica, v.4, n.2, p.1-12, 2004. DOI: http://doi.org/10.1590/S1676$\underline{06032004000200002}$

VIEIRA, T. Q.; SILVA, F. B. DA; HEUBEL, M. T. C. D.. Biometria, hematologia e genética de Caiman latirostris (Daudin, 1801) na região de Bauru (SP). Saluvista, v.21, p.67-75, 2002.

WANG, S.; LIU, Y.-J.; TIAN, L.-X.; XIE, M.-Q.; YANG, H.-J.; WANG, Y.; LIANG, G.-Y.. Quantitative dietary lysine requirement of juvenile grass carp Ctenopharyngodon idella. Aquaculture, v.249, n.1-4, p.419-429, 2005. DOI: http://doi.org/10.1016/j.aquaculture.2005.04.005

WEBB, R. E.; LESLIE JR., D. M.; LOCHMILLER, R. L.; MASTERS, R. E.. Immune function and hematology of male cotton rats (Sigmodon hispidus) in response to food supplementation and methionine. Comparative Biochemistry and Physiology Part A: Molecular \& Integrative Physiology, v.136, n.3, p.577-589, 2003. DOI: http://doi.org/10.1016/S10956433(03)00209-5

ZIMMERMAN, L. M.; VOGEL, L. A.; BOWDEN, R. M.. Understanding the vertebrate immune system: insights from the reptilian perspective. Journal of Experimental Biology, v.213, n.5, p.661-671, 2010. DOI:

http://doi.org/10.1242/jeb.038315

A CBPC - Companhia Brasileira de Produção Científica (CNPJ: 11.221.422/0001-03) detém os direitos materiais desta publicação. Os direitos referem-se à publicação do trabalho em qualquer parte do mundo, incluindo os direitos às renovações, expansões e disseminações da contribuição, bem como outros direitos subsidiários. Todos os trabalhos publicados eletronicamente poderão posteriormente ser publicados em coletâneas impressas sob coordenação da Sustenere Publishing, da Companhia Brasileira de Produção Científica e seus parceiros autorizados. Os (as) autores (as) preservam os direitos autorais, mas não têm permissão para a publicação da contribuição em outro meio, impresso ou digital, em português ou em tradução. 